\title{
Correction to: Are Artificially Intelligent Conversational Chatbots Uniformly Effective in Reducing Summer Melt? Evidence from a Randomized Controlled Trial
}

\author{
Aizat Nurshatayeva ${ }^{1}$ (D) Lindsay C. Page ${ }^{1} \cdot$ Carol C. White $^{2} \cdot$ Hunter Gehlbach $^{3}$
}

Published online: 18 May 2021

(c) Springer Nature B.V. 2021

\section{Correction to: Research in Higher Education (2021) 62:392-402 https://doi.org/10.1007/s11162-021-09633-z}

The original version of this article, unfortunately, contained a mistake in Table 3 . In the last row of Table 3, the value "659" under the 5th column should read as "1659". The correct Table 3 is presented below.

The original article can be found online at https://doi.org/10.1007/s11162-021-09633-z.

Aizat Nurshatayeva

ain7@pitt.edu

Lindsay C. Page

lpage@pitt.edu

Carol C. White

ccw489@msstate.edu

Hunter Gehlbach

gehlbach@jhu.edu

1 School of Education, University of Pittsburgh, Pittsburgh, PA, USA

2 College of Education, Mississippi State University, Starkville, MS, USA

3 School of Education, Johns Hopkins University, Baltimore, MD, USA 
Table 3 Statistics on the interactions between PeeDee and the treatment ECU-intending students

\begin{tabular}{|c|c|c|c|c|c|c|}
\hline & (1) & (2) & (3) & (4) & $(5)$ & (6) \\
\hline & \multicolumn{2}{|c|}{ All treated students } & \multicolumn{2}{|c|}{$\begin{array}{l}\text { First-generation } \\
\text { students }\end{array}$} & \multicolumn{2}{|c|}{$\begin{array}{l}\text { Non-first-generation } \\
\text { students }\end{array}$} \\
\hline & Mean (SD) & Range & Mean (SD) & Range & Mean (SD) & Range \\
\hline Opt out & $0.06(0.23)$ & $0-1$ & $0.05(0.21)$ & $0-1$ & $0.06(0.24)$ & $0-1$ \\
\hline Messages sent by PeeDee to students & $26.37(7.51)$ & $3-97$ & $26.52(7.68)$ & $3-97$ & $26.32(7.45)$ & $3-96$ \\
\hline Messages sent by students to PeeDee & $3.36(4.53)$ & $0-52$ & $3.24(4.98)$ & $0-52$ & $3.40(4.37)$ & $0-34$ \\
\hline $\begin{array}{l}\text { Number of days during which stu- } \\
\text { dents sent messages to PeeDee }\end{array}$ & $1.42(1.71)$ & $0-22$ & $1.38(1.94)$ & $0-22$ & $1.43(1.63)$ & $0-13$ \\
\hline Observations & 2205 & & 546 & & 1659 & \\
\hline
\end{tabular}

According to t tests, there are no statistically significant differences between the first-generation and nonfirst-generation students in all four variables measuring the interactions with the chatbot. The number of treated students here is 2205 (not 2221) because 16 students in the treatment group assigned to receive text outreach didn't receive it and so they aren't included in the table

$* * * \mathrm{p}<0.01, * * \mathrm{p}<0.05, * \mathrm{p}<0.1$

Publisher's Note Springer Nature remains neutral with regard to jurisdictional claims in published maps and institutional affiliations. 